\title{
PERSONALITY TRAITS OF THE CRIMINAL ENCROACHING ON THE PUBLIC RELATIONS ENSURING THE INVIOLABILITY OF THE PERSONAL (PHYSICAL) FREEDOM IN RUSSIA
}

\author{
ALEKSANDR N. KALIUZHNYI \\ NIKOLAI G. SHURUKHNOV
}

\begin{abstract}
The study of man by the methods of such sciences as psychology, sociology, forensic science and criminology makes it possible to substantiate the individuality of a person and the dependence of his actions and actions on the formed interests, value orientations, ideals, life goals representing personality traits. These signs determine the behavior of the victim, provoke the perpetrators to commit a crime, affect the methods of committing a crime. Based on a study of 320 criminal cases of violations of personal freedom, the victims are classified into two groups: a) victims who were intended for physical exploitation in order to obtain material benefits; b) victims whom the criminals did not plan to exploit, but intended to get a ransom for them, to appropriate their vehicles and property vehicles. Each of these groups is characterized by specific personality traits, the knowledge of which allows you to establish the circumstances of the crime, which are guidelines for organizing an investigation, extension and version control, searching for traces and means of crime, and ultimately identifying the offender.
\end{abstract}

Keywords: personality; criminal; personal freedom; investigation; classification of victims; reasons for attacks on freedom

Klíčová slova: osobnost; zločinec; osobní svoboda; vyšetřování; klasifikace obětí; příčiny útoků na svobodu

DOI: $10.14712 / 23366478.2020 .6$

\section{INTRODUCTION}

It is believed that the essence of the personality consists in expressing individuality through the way of being and entering into social relations, personifying it in society. Individual consciousness, focus and specificity of activities depend not only on the position in society, but also on the internal attitude to their place in it which is determined by interests, value guides, ideals, employment, goals of social activity. ${ }^{1}$

A person is individual not only by the features of his face, physique, gait, manner of behavior but also by the originality of his inner world - personality traits that determine a peculiar attitude to certain aspects of reality, preference of some values over others.

1 SCHIMMENTI, A. - PASSANISI, A. - PACE, U. - MANZELLA, S. - CARLO, G. - CARETTI, V. The Relationship Between Attachment and Psychopathy: A Study with a Sample of Violent Offenders. Current Psychology, 2014, Vol. 33, No. 3, pp. 256-270. 
This behavior is due to psychological properties, their complex selective implementation in practice. ${ }^{2}$ This is most evident in the commission of crimes.

Each crime is an exceptional unlawful act depending on the preparation, the mode of commission, the dynamics of the mechanism, the localization of traces, the direction of intent, concealment techniques, the subject's readiness to resist the investigation. The nature, severity, voluminosity, direction listed above are interdependent with the type of unlawful act and personality characteristics of the subject of the crime. ${ }^{3}$ They determine the impossibility or possibility of establishing the fact of the crime committed.

\section{THEORETICAL BASIS OF THE RESEARCH}

The analysis of materials of 320 criminal cases infringing on the personal freedom (abduction [kidnapping], illegal confinement, use of slave labor, human trafficking, illegal placement in a psychiatric hospital) investigated in the period from 1998 to 2018 in Russia 4 allows us to conclude that the offences in question are committed by persons who have specific personality characteristics that distinguish them from the subjects of other crimes. They are characterized by cruelty, extreme egoism, disregard for others, heartlessness, the ability to inflict any bodily harm, the use of sophisticated methods of committing crimes, the lack of compassion and positive social guidelines. ${ }^{5}$

The study of criminal cases, conversations with investigators allow us to say that persons who have committed crimes that violate personal freedom have mixed personality traits that are characteristic, on the one hand, for a mercenary criminal ${ }^{6}$ and, on the other hand, for violent ones, ${ }^{7}$ which distinguishes them from subjects of economic, tax, environmental crimes.

The set of these personality traits, their interdependencies (internal correlations) make it possible to establish specific circumstances that serve as a guideline in determining the direction of investigation, extension and version control, searching for traces and means of committing crimes, accomplices in illegal activities, and prevention of these crimes too. ${ }^{8}$ In turn, this affects the choice of tactics for executing investigative

2 ALISON, L. - BENNELL, C. - MOKROS, A. - ORMEROD, D. The personality paradox in offender profiling: A theoretical review of the processes involved in deriving background characteristics from crime scene actions. Psychology, Public Policy, and Law, 2002, No. 8, pp. 115-135.

3 OZIEL, S. - GOODWILL, A. - BEAUREGARD, E. Variability in Behavioural Consistency Across Temporal Phases in Stranger Sexual Offences. Journal of Police and Criminal Psychology, 2015, Vol. 30, No. 3, pp. 176-190.

4 According to the data from the Russian Information and Security Center of the Ministry of the Interior of Russia, in 2017, 863 crimes were registered, which are stipulated by chapter 17 of the Criminal Code of the Russian Federation.

5 HANSON, K. - BUSSIERE, M. Predicting relapse: A meta-analysis of sexual offender recidivism studies. Journal of Consulting and Clinical Psychology, 1998, No. 66, pp. 348-362.

6 YEGOROV, V. Personality of a tax criminal. Actual problems of economics and law, 2010, Vol. 2, No. 14, pp. 149-155.

7 SMIRNOV, A. The identity of a violent criminal recidivist. Eurasian legal journal, 2010, Vol. 6, No. 25, pp. 113-117.

8 HAKKANEN, H. - LINDLOF, P. - SANTTILA, P. Crime scene actions and offender characteristics in a sample of Finnish stranger rapes. Journal of Investigative Psychology and Offender Profiling, 2004, No. 1, pp. 17-32. 
actions, force the subject of the investigation to think over the arsenal and time for implementation.

Studying the investigative practice, we have come to the conclusion that the criminals who encroach on the public relations ensuring the inviolability of personal (physical) freedom belong to two main groups depending on the legal status and personality traits.

Based on this, the first group will consist of persons who are not special subjects and who are not authorized by law to ensure the protection of human and civil rights and freedoms in the Russian Federation. This group is the most numerous, it was made up $92.8 \%$ of the subjects of crime.

The second group will consist of persons with the status of a special subject, they are authorized to comply with the legislation in the field of ensuring personal freedom including in the field of protecting the rights and interests of children by parents. It includes $7.2 \%$ of persons prosecuted.

This percentage is due to a number of reasons: 1) the overwhelming majority of crimes involving responsibility for abduction and illegal confinement $(94.8 \%) ; 2)$ the specifics of the socio-economic situation in Russia, indicating a relatively high level of unemployment determining the jobless population to solve material problems in a criminal way $; 3$ ) the increase of legal nihilism among the population. ${ }^{10}$

\section{THE FIRST GROUP OF CRIMINALS}

More than half $(60.1 \%)$ of the subjects of the first group crimes did not have a permanent source of income and a stable place of work. Let's pay attention to the fact that in 2018 in Russia there was a decrease (by 5.4\%) of the criminal activity of persons who do not have a regular income. 601,252 people from the named subgroup took part in illegal activities. The number of unemployed people who committed crimes increased by $8.7 \%$ (4,775 people). The shares of workers and employees who committed crimes, encroaching on public relations ensuring the inviolability of personal (physical) freedom were distributed approximately equal and amounted to $19.5 \%$ and $14.5 \%$.

The number of pupils and students who have committed unlawful encroachment provided by the Chapter 17 of the Criminal Code was 5.1\%. It should be noted that in 2018 the number of pupils and students who committed crimes in the Russian Federation decreased by $2.1 \%$ (in 2017 - 45,504 such subjects were identified, in $2018-44,430$ ).

Most of the perpetrators of the crimes in question did not have a family $(67.7 \%)$; they were not married. Experts who have studied this problem in relation to the certain elements of the crimes included in the Chapter 17 of the Criminal Code of the Russian Federation have come to the following conclusion: "The fact that a typical criminal in

9 GURNITSKIY, A. The identity of the offender, classified as poor. Society and law, 2014, Vol. 2, No. 48, pp. $152-157$.

10 VENEDIKTOV, N. The identity of the offender in criminology and criminology. Bulletin of Tomsk State University, 2014, No. 384, pp. 148-152. 
this category does not work anywhere and is not married indicates a negative attitude to useful social work and to family values. In turn, it suggests that he has an antisocial attitude."11

As well as any crimes, encroachments on the personal freedom are determined by the motives of their commission. The motive of the crimes that are the subject of our research, as well as the others, is made up of the criminal's attitude to the real goal (the desired result) and acts as an incentive for the realization of the plan. ${ }^{12}$ Among them prevailed: self-interest $-80 \%$; sexual attraction, the desire to start a family, have a woman $-9.1 \%$; vengeance, personal hostile relations $-5.9 \%$; others $-5 \%$.

The predominance of self-interest when committing crimes under the Chapter 17 of the Criminal Code of the Russian Federation is due to the desire focused on a thoughtful way to commit illegally causing physical and moral suffering to the victim and often to his inner circle, to gain material benefits relatively quickly and also to receive money (it is the most often figured as the demand of criminals), property or right of ownership, use and disposal of the property. ${ }^{13}$

It should be noted that often the demand for ransom for the release of the victim is also used to resolve economic issues (disputes) including the inducement of the co-owner to active implementation of the assigned business development responsibilities and the debtor to performance his obligations arising from conditions of the loan agreement, other contracts and also from non-contractual obligations. ${ }^{14}$

So, N. and V. conducted joint business activities related to the operation of the beach on the reservoir. When discussing further actions to develop business and obtain a differentiated income, disagreements arose between them which later grew into hard aversions which could not be resolved. In order to exclude V. from business, N. decided to exert physical influence on him. For this, together with G., they stoled by deception V., tied him up, put him in the luggage compartment of the car, took him to the forest and after rejecting the ultimatum put forward by N., they committed the murder of $\mathrm{V} .{ }^{15}$

Selfish motives can also be traced in attacks aimed at the labor and sexual exploitation of victims. ${ }^{16}$

The report of the Director of the UN Office on Drugs and Crime, Antonio Maria Costa, noted that human trafficking remains a significant problem for more than 15 years in a row. It was noted that the main suppliers were the Baltic countries and the former Soviet Union. They accounted for $32 \%$ and $19 \%$ of all victims in the sex industry in

11 KARASEVA, M. Criminal liability for crimes against individual freedom. Dissertation of the candidate of legal sciences. Moscow, 2007, 186 p.

12 NAVIA, C. - OSSA, M. Family Functioning, Coping, and Psychological Adjustment in Victims and Their Families Following Kidnapping. Journal of Traumatic Stress, 2003, Vol. 16, No. 1, pp. 107-112.

13 SELTEN, R. A Simple Game Model of Kidnapping. Models of Strategic Rationality. Part of the Theory and Decision Library C, book series, 1988, pp. 77-93.

14 VOLKOV, A. Legal and forensic problems of identifying and disclosing a person's abduction. Dissertation of the candidate of legal sciences. Moscow, 2002, $192 \mathrm{p}$.

15 Archive of the Moscow Regional Court, 2013, Criminal Case No. 2-34.

16 KURSAYEV, A. The identity of the criminal, using slave labor. Altai legal Bulletin, 2017, Vol. 3, No. 19, pp. 93-97. 
Europe. $79 \%$ of the victims of human trafficking worldwide were victims of sexual exploitation, $20 \%$ of whom were children. ${ }^{17}$

By virtue of their specificity (mechanism of illegal activity), $64.7 \%$ of considered crimes cases are committed by a group of persons, $4.3 \%$ of which are organized criminal groups, in $31 \%$ by alone criminal. The presence of the group nature of such attacks is indicated by many authors. ${ }^{18}$

It should be noted that in 2018 an increase in crimes committed by organized groups and criminal associations (criminal organizations) was registered by $17.9 \%$, with a high increase of $140 \%$ for abductions. ${ }^{19}$

A significant level of the group nature of crimes aimed at personal freedom is explained by a number of different reasons, including the difficulty of committing such crimes alone, for example, kidnapping (except for children). ${ }^{20}$

As already mentioned, the level of preparation, the search for the appropriate situation, the choice of methods of committing attacks on personal freedom, concealment techniques, and countering the investigation depend on the personal characteristics of the subjects. Here a considerable role belongs to the level of education of the criminal, prior criminal experience.

The persons studied are characterized by the following educational level: $21.2 \%$ had a higher education, $66.7 \%$ had a secondary vocational or secondary general, and only $12.1 \%$ of criminals who committed an encroachment on public relations that ensure the inviolability of personal (physical) human freedom had the main general or primary education. $22.2 \%$ were previously convicted for various crimes. It should be noted that the previous experience of committing unlawful acts, staying in places of deprivation of liberty added not only the experience of committing crimes, but also had an impact on the methods of committing the studied crimes, the selection of accomplices and the means of committing. The given facts corrected also properties of the person, adding cruelty, callousness, soullessness to acts.

The vast majority (92.3\%) of crimes that infringe upon personal freedom are committed by males. ${ }^{21}$ This indicator is traditional; the proportion of women who committed crimes in the Russian Federation in 2018 was 15.6 thousands. This is $2.6 \%$ more than in 2017. A large number of male criminals is explained by the need to use physical violence, overcoming the resistance of victims, according to such acts as abduction, unlawful imprisonment.

17 DZHORDAN, E. An Annotated Guide to the UN Protocol Against Trafficking in Persons. Moscow, Nauka, 2005.

18 CLUTTERBUCK, R. Organization of a Long-term Kidnap. In: Kidnap, Hijack and Extortion: The Response. Palgrave Macmillan, London, 1987.

19 Comprehensive analysis of the state of crime in the Russian Federation in 2018 and the expected trends in its development. Analytical review. M., 2019, p. 45.

20 VANNINI, M. - DETOTTO, C. - MCCANNON, B. Ransom Kidnapping. Encyclopedia of Law and Economics. Springer, New York, NY, 2019.

21 Juveniles committed $2.4 \%$ of the crimes in question. 
A small number of women belonging to the subjects of the first group is explained by the anatomical and physiological features of the body, psyche, sensual, volitional, emotional spheres, psychological perception of the environment. ${ }^{22}$

The role of women in these crimes, as a rule, is reduced to complicity, at least - to co-execution. ${ }^{23}$ So, V., together with M., getting acquainted with low-income and socially unprotected girls on the Internet, in the course of correspondence and telephone conversations offered the latter to come to Moscow for prostitution. Further, they intended to sell them into sexual slavery to wealthy clients. ${ }^{24}$

The analyzed crimes are committed mainly by persons of two age groups: $18-29$ years old $-47.5 \%, 30-49$ years old $-43.1 \%$. This pattern can be explained by a number of non-complex factors, including: an active and productive period of human activity; possessing sufficient physical strength; the ability to use the most of intellectual abilities; the presence of certain professional skills (driving, ability to handle weapons, communications, video surveillance).

\section{THE SECOND GROUP OF CRIMINALS}

The second group of persons encroaching on public relations, ensuring the inviolability of personal (physical) freedom are special subjects. As already mentioned, they are authorized to ensure the rights and freedoms of a person and a citizen in accordance with generally accepted principles and norms of international law and in accordance with the Constitution of the Russian Federation. ${ }^{25}$ Such special subjects were doctors (medical personnel) of maternity hospitals, psychiatric hospitals, ${ }^{26}$ parents of newborns or young children, ${ }^{27}$ law enforcement officers ${ }^{28}$ (according to our data, they amounted to a total of $7.2 \%$ ).

The subjects of this group are characterized by the presence of a clear goal, the connection of the powers that they perform with the realization of the right to personal freedom, a streamlined system of actions, discipline and secrecy. The great organization and thorough concealment of the group of crimes under consideration are due to the pe-

22 SHEVCHENKO, L. Personality of a criminal in a gender dimension. Personality, family and society: questions of pedagogy and psychology, 2016, Vol. 12, No. 69, pp. 33-41.

23 BEAUREGARD, E. - LUSSIER, P. - PROULX, J. Criminal profiling: International theory, research, and practice. Humana Press, Totowa, NJ, 2008, pp. 89-113.

24 Archive of the Perovsky District Court of Moscow, 2016, Criminal Case No. 01-009.

25 KUZ'MIN, M. The identity of the criminal with a special legal status as an element of the criminalistic characteristics of crimes. Investigation of crimes: problems and ways to solve them, 2014, Vol. 6, No. 6, pp. 213-221.

26 The psychiatrist determines the indications for emergency hospitalization, and, if necessary, organizes it in accordance with the legislation of the Russian Federation.

27 DE BOER-BUQUICCHIO, M. Sale of Children and Trafficking in Children as International Crimes. In: WINTERDYK, J. - JONES, J. (eds). The Palgrave International Handbook of Human Trafficking. Palgrave Macmillan, Cham, 2019.

28 FOLAMI, O. - NAYLOR, R. Police and cross-border crime in an era of globalisation: The case of the Benin-Nigeria border. Secur J., 2017, No. 30, pp. 859. 
culiarity of the professional activity. ${ }^{29}$ They are empowered to make certain decisions, to accompany them with the preparation of relevant "objective" documents that restrict the freedom of the victim, as well as the actual enjoyment of the freedom of other people (children, offenders).

A significant number of the subjects of this group are men $-65.2 \%$, but their number is lower than the criminals of the previously represented group. As a rule, men of this group commit encroachments related to the abduction of people and the unlawful deprivation of their liberty being law enforcement officers. ${ }^{30}$

$34.8 \%$ of subjects are women. Their illegal activities are related to the abduction and sale of children, less often the illegal placement of the victim in a psychiatric hospital. ${ }^{31}$

Self-interest motivation is also characteristic of these subjects ${ }^{32}(56.5 \%$ according to our research). In other cases, the desire to help women who have no opportunity to give birth the child themselves thereby strengthening family relations is dominated in $30.4 \%$ of cases. $^{33}$

As a motive, there are also falsely understood service interests $-13.1 \%$ (to raise the performance indicators, to discover or solve a crime not committed by a specific person, all this is accompanied by unlawful deprivation). ${ }^{34}$ So, K., M. and Y. being police officers, knew that $Z$. was involved in the distribution of narcotic drugs and psychotropic substances, they drove up to Z.'s house and deceptively called fraudulently the latter outside. They showed IDs of police officers, then they applied a few punches to his head, handcuffed him, shoved him into a car and took him to the police station No. 32 of the Nevsky District of St. Petersburg where they illegally held him demanding to name the drug dealers. ${ }^{35}$

Among the represented subjects $65.2 \%$ had a higher education. The age ranged from 20 to 30 years $-21.7 \%$, from 30 to 40 years $-43.5 \%$, 40 to 50 years $-26.1 \% .52 .2 \%$ were married, of which $21.7 \%$ were in civilian life.

29 PSHIVA, R. - SUAREZ, G. Capital crimes: kidnappings and corporate investment in Colombia. In: DI TELLA et al. (ed.). The economics of crime: lessons for and from Latin America. Chicago, National Bureau of Economic Research, 2010.

30 Archive of the Oktyabrsky District Court of Belgorod, 2017, Criminal Case No. 1-305; archive of the Bryansk Regional Court, 2017, Criminal Case No. 2-08; archive of the Smolninsky District Court of St. Petersburg, 2010, Criminal Case No. 1-31.

31 Archive of the Zavodskoy District Court of the city of Orel, 2017, Criminal Case No. 1-149; archive of the Zelenograd District Court of Moscow, 2011, Criminal case No. 1-154; archive of the Gagarinsky District Court of Moscow, 2018, Criminal Case No. 3. 1-0018.

32 DESAI, M. - GOEL, S. Child Rights to Prevention of Commercial Exploitation. In: Child Rights Education for Inclusion and Protection. Rights-based Direct Practice with Children. Springer, Singapore, 2018.

33 HORNER, C. My Child, Your Womb, Our Contract: The Failure of Contract Law to Protect Parties in Gestational Surrogacy. In: CAMPO-ENGELSTEIN, L. - BURCHER, P. (eds). Reproductive Ethics. Springer, Cham, 2017, pp. 137-149.

34 KARASEVA, M. Criminal liability for abduction of a person. Bulletin of the North-Caucasian State Technical University, 2017, Vol. 4, No. 31, pp. 148-152.

35 Archive of the Nevsky District Court of St. Petersburg, 2014, Criminal Case No. 1-125. 


\section{CONCLUSION}

The given personality traits of a modern criminal who encroach on public relations, ensuring the inviolability of the personal (physical) freedom, allow us to bring up the following typical portrait. He is a man aged 18 to 49 years old, having a general secondary education, not working, not having a permanent job and income, single, characterized by a persistent antisocial attitude, having various special skills, focused on a criminal lifestyle, committing crimes with a mercenary motive and preferring a group form of violent encroachment. Their common personal traits are egoism, disregard for others, lack of positive social guidelines, the use of sophisticated methods of committing crimes.

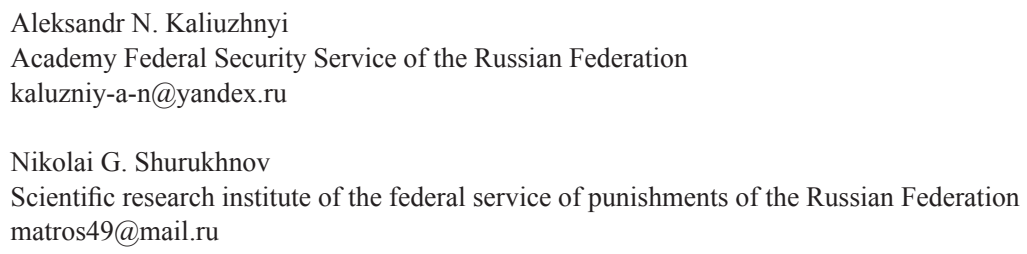

